\title{
Maritime activity and the Divine - an overview of religious expression by Mediterranean seafarers, fishermen and travellers
}

\author{
Timmy Gambin
}

\begin{abstract}
Over the past decades, modern technologies such as electronic navigational aids, improved ship designs and accurate weather forecasts have all contributed to making maritime activity safer. However, even today the undertaking of a journey by sea or even a fishing trip involves varying degrees of danger. Over the centuries, those involved with earning a living at sea, as well as those simply travelling by ship, have invoked specific rituals and developed particular superstitions. These could be aimed at alleviating fears, supplication for a safe journey or simply to plea for a bumper catch. The relationship between seafarers and the divine is not limited to a particular chronological period, religion or geographical zone. The aim of this paper is to illustrate broadly how the maritime-divine link has manifested itself through time. The presentation has been divided into a number of themes that include ritual, iconography and the deities themselves. ${ }^{1}$
\end{abstract}

Key words: maritime religion, ritual, seafaring, navigation

\section{Introduction}

Humans are creatures of the land. The sea is not an environment that is conducive to human survival. The very posture of human beings, standing on two legs that are firmly placed on the ground, is taken away when one enters the water to swim. Whilst swimming, the normal point of view enjoyed by humans is also changed. We no longer have a relatively high vantage point and cannot see below us. Even those with the keenest of eyesight are hard pressed to see beyond the blur that welcomes those who open their eyes under water. Out of the water, some are imbued with a sense of fear and trepidation just by standing on the coast looking out to sea. Such a sense of apprehension is clearly described in some of the earliest texts from the eastern Mediterranean. ${ }^{2}$ Despite such fears the sea is also a place of opportunity. Through fish, molluscs, seaweed and salt it has provided food, one of the vital elements for human survival. Above else, however, the sea has enabled humans to travel. Journeys undertaken across open sea spaces have pushed humans to move and occupy some of the more remote corners of our planet. Our ancestors quite literally took the risk of sailing into the unknown in search of resources and new lands where better lives could be made - often escaping pressures building at home. Whereas such individuals and groups took to the sea out of necessity others did so out of choice, to trade and exchange goods. Such exchange created networks that started to link areas of production with areas of consumption. In a Mediterranean context such networks

\footnotetext{
${ }^{1}$ Correspondence: Dr. Timmy Gambin, Department of Classics and Archaeology, University of Malta, Msida, Malta. E-mail: timmy. gambin@um.edu.mt.

${ }^{2}$ Elisha Linder, 'Human apprehension of the sea', in The Sea in History, ed. E.E. Rice (Phoenix Mill: Sutton 1996), pp. 15-23.
}

expanded and contracted through history according to the surrounding geo-political landscape prevailing at the time.

Over the millennia, the continuous use of the sea has produced distinct groups of people including seafarers, fishermen, boatbuilders, merchants and others, whose lives and livelihood are directly linked to the sea. As for people who used the sea, one must also add those that travelled by sea but whose livelihood did not depend on it. Such persons would have included pilgrims, warriors and migrants. In this paper, my intention is to explore how people at sea developed specific and distinct religious beliefs and practices to relate to/move through/survive in this environment. Whereas the geographical focus of this paper is the Mediterranean, I propose that the unique links between the aforementioned people and the divine transcends geographical, cultural as well as chronological boundaries.

It is beyond this paper's scope to dwell upon philosophical questions as to what defines or comprises a religion. Reference to the Oxford English Dictionary reveals two plausible definitions for the purpose of this paper:

1. Action or conduct indicating belief in obedience to, and reverence for a God, gods or similar superhuman power

2. A particular system of faith or worship

Both these definitions cover the various aspects discussed below. In order to undertake a broad overview of this matter and garner a better understanding of maritime religious expression, I have divided discussion in this paper into these expressions, following four analytical categories:

1. Deities

2. Ritual

3. Maritime cultic landscapes

4. Dry offerings 


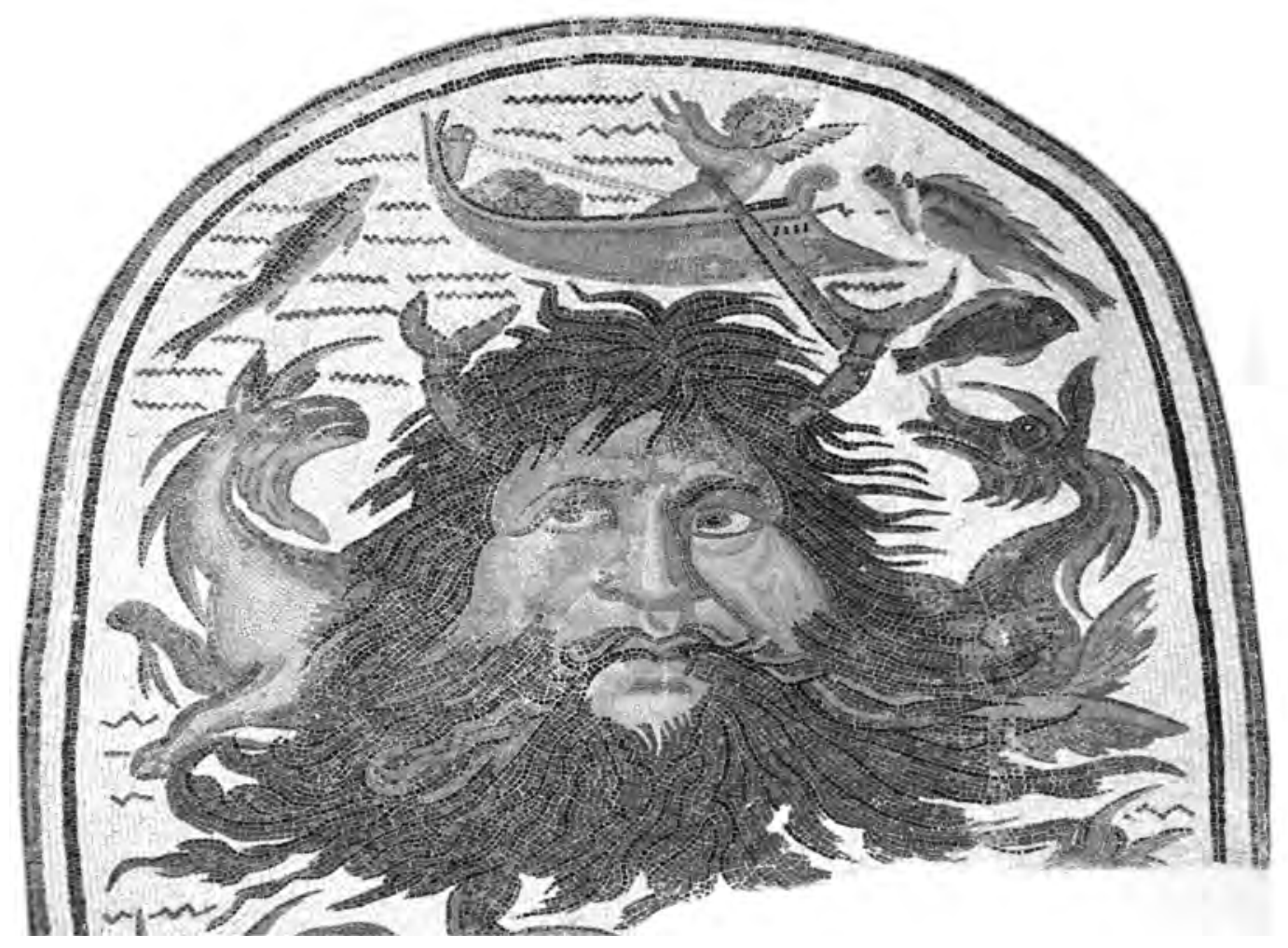

Fig. 1: A ROMAN MOSAIC fROM TUNISIA PORTRAYING NePtUNe (PHOTO T. GAMBIN).

\section{Deities}

In the ancient religions of the Mediterranean, some form of activity and/or deity was nearly always associated with the sea. In the Late Neolithic, the inhabitants of the Maltese Islands constructed places of worship in prime coastal areas with one specific megalithic structure containing depictions of sea creatures. ${ }^{3}$ For the Caananites, the god Yam represented the sea with its raw and untamed power and a negative perception that is ever-present in early biblical texts. Also from the Levantine pantheon Astarte travels to Egypt and takes on a role of 'intermediary between the Ennead of the Gods and the Sea'. ${ }^{4}$ Astarte was to retain a special place in the hearts of seafarers as is reflected in the numerous votive offerings bearing her name and which were discovered in the multi-period maritime sanctuary at Tas-Silg that overlooks the harbour of Marsaxlokk in Malta. ${ }^{5}$ The Greek god of the sea, Poseidon, was the brother of Zeus and Hades. There are two sides to Poseidon (or Neptune in the Roman pantheon) - that of a creator of islands and calm seas contrasting with his role as the creator of earthquakes, drowning and shipwrecks (Fig. 1).

\footnotetext{
${ }^{3}$ Reuben Grima, 'The landscape context of Megalithic architecture', in Malta Before History, ed. Daniel Cilia (Sliema, Malta: Miranda Publishers, 2004), pp. 327-346.

${ }^{4}$ Peter Serracino Inglott, 'The sea in the Bible', in De Triremibus: A Festschrift in Honour of Joseph Muscat, eds. Tony Cortis and Timmy Gambin (M’Scala, Malta: PEG Books, 2005), pp. 3-10; Linder, 14-22. ${ }^{5}$ Anthony J. Frendo and Nicholas C. Vella, 'Les îles phéniciennes du milieu de la mer Malte du Néolithique à la conquête normande’, Dossiers d'Archéologie, 267 (2001): 46-55.
}

Despite it being quite evident that most gods of the sea were male, the role of an intermediary at sea, more specifically a female one, was common throughout the Mediterranean. In Greece, an early reference to such an intervention can be noted from the pages of the Odyssey. It is Athena who intervenes numerous times on Odysseus' behalf, most notably in the context of this study when she pleads with Zeus who relents and sends Hermes with instructions for the hero to return home. ${ }^{6}$ The notion of female deities and their association with intervention at sea continues well into Roman times. In Alexandria, the twin-cult of Isis-Sarapis was much adhered to by seafarers undertaking the transport of grain from Egypt to Italy. ${ }^{7}$ In various Mediterranean regions, the Navigium Isidis was a festival held in early March in honour of the goddess Isis. The opening of the sailing season was marked during this festival by the launching of model boats (loaded with offerings) into the sea. ${ }^{8}$

The notion of a female deity associated with intervention on behalf of seafarers continued and was essentially adopted into the Christian pantheon. ${ }^{9}$ Our Lady is seen by Christian seafarers as providing a direct link between themselves and the Almighty - for what better way to reach the son than through devotion to the mother? Some

\footnotetext{
${ }^{6}$ The Odyssey, translated by E.V. Rieu (London: Penguin Classics, 2003), 5:30.

${ }^{7}$ David Fabre, Seafaring in Ancient Egypt (London: Periplus Publishing, 2004), p. 200.

${ }^{8}$ James Beresford, The Ancient Sailing Season (Leiden: E.J. Brill, 2012), p. 41; Fabre, 200.

${ }^{9}$ Ruthi Gertwagen, 'The emergence of the virgin Mary as the patron saint of seafarers’, Journal of Mediterranean Studies, 16 (2006): 149-161.
} 
of the earliest nautical charts depict Our Lady as presiding over the seas and oceans. Seated with Jesus on her lap she oversees all that happens at sea. As explored below, it is to her mainly that Christian seafarers directed numerous rituals and offerings. As the mother of Our Lady, St. Anne also assumed a role in the Christian maritime milieu. Although not as widespread as the devotion to her daughter, St. Anne was venerated amongst sailors from the Atlantic coast of France where the church of Sainte Anne de-la-Pathe is a centre of this cult. ${ }^{10}$ It was in fact French fishermen who took this cult across the Atlantic to Quebec. In the Mediterranean, St. Anne is known to have been held in high esteem on Spanish vessels ${ }^{11}$ and the Order of St. John named of their largest ships Santa Anna. ${ }^{12}$

Essentially the Christianisation of large parts of the Mediterranean brought with it a gradual increase in minor deities (saints) with varying degrees of influence on those working and travelling at sea. These include saints with particular domains such as St. Andrew, patron saint of fishermen, St. Nicholas, patron saint of travellers, as well as others including St. Paul, St. Elmo and St. Christopher. ${ }^{13}$

\section{Rituals}

The study of ancient rituals is, at best, difficult. Archaeology does sometimes provide the remains of the physical setting within which it is assumed that rituals were performed. Such places can include temples, small sanctuaries and old churches. In the context of maritime rituals there are three main places where rituals are undertaken: 1) on the coast, 2) in maritime sanctuaries, and 3) on board the vessels themselves. I am here referring to rituals that are specifically and directly linked to journeys at sea. (In the section on 'dry offerings' below, other rituals that may be deemed to be indirectly linked to sea voyages are discussed.)

Given that rituals at sea were carried out on ships it is extremely difficult to study the remains of such rituals. Most commonly, the archaeology of ancient shipwrecks presents us with the remains of ceramic cargoes and possibly some limited wooden remains. ${ }^{14}$ We are limited to a small number of material objects such as louteria (small portable altars/platforms) that are thought to have been used for onboard rituals (Fig. 2). ${ }^{15}$

\footnotetext{
${ }_{10}$ J. Gordon Melton, ed., Religious Celebrations: An Encyclopedia of Holidays, Festivals, Solemn Observances and Spiritual Commemorations (Santa Barbara, CA: ABC CLIO, 2011), p. 36.

${ }^{11}$ Fletcher S. Bassett, Legends and Superstitions of the Sea, and of Sailors in all Lands and at all Times (Chicago and New York: Belford, Clarke, 1885), p. 315.

12 See Joseph Muscat, The Carrack of the Order (Valetta: PIN Publications, 2000).

${ }^{13}$ Catherine Rachel John and Donald Attwater, The Penguin Dictionary of Saints (London: Penguin Books, 2005)

${ }^{14}$ Anthony J. Parker, 'The reservation of ships and artifacts in ancient Mediterranean wreck sites', Progress in Underwater Science, 5 (1980): 41-70.

${ }^{15}$ Irena Radic Rossi, 'Three more louteria from the Eastern Adriatic', International Journal of Nautical Archaeology, 20 (1991): 155-160.
}

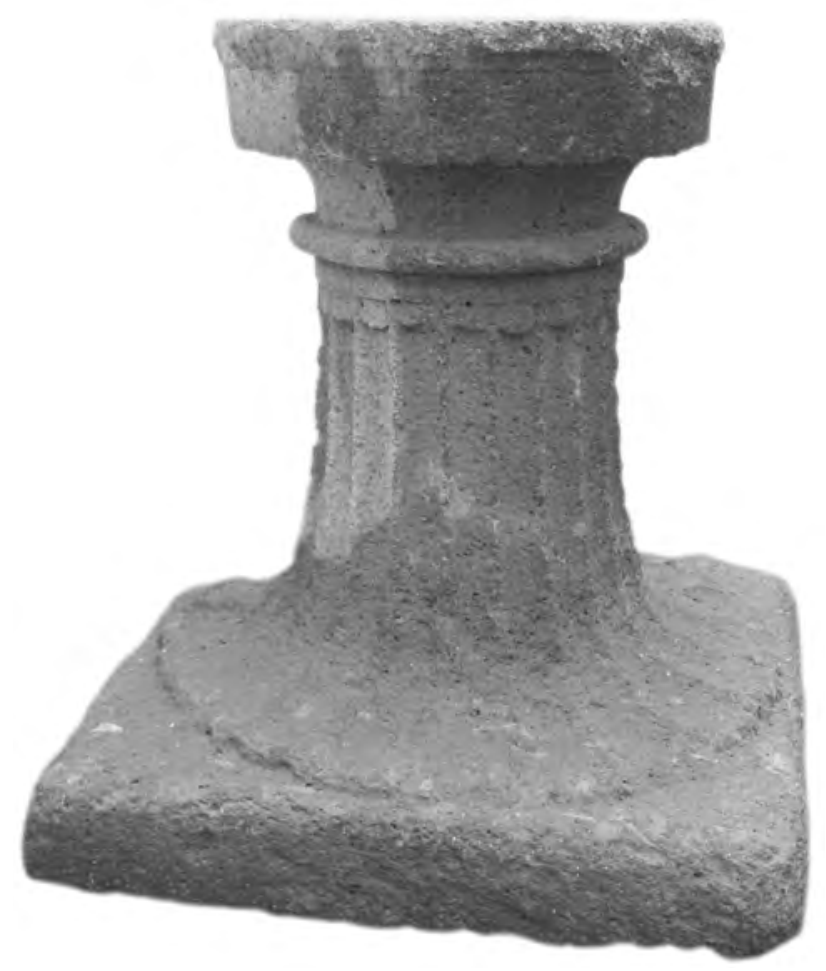

FIG. 2: A LOUTERION FROM THE THIRD CENTURY CE SITE III IN FILICUDI, SICILY (PHOTO T. GAMBIN).

Otherwise it is written sources that describe such specialised manifestations of maritime devotion related to sacrifices, offerings and prayers. Once again the Odyssey contains a description of such activity. Whilst travelling in search of his father, Telemachus comes across persons carrying out a ritual: 'they found the people [of Pylos] on the seashore sacrificing jet-black bulls to Poseidon'. When he and Athena joined Nestor at the banquet they were passed a gold cup with wine as a 'drink offering' upon receiving the cup, Athena uttered this prayer:

'Hear me, Poseidon, Sustainer of Earth, and do not grudge us, your suppliants, the fulfilment of our wishes. First of all, grant glory to Nestor and his sons. Consider next these others, and recompense all in Pylos for their sumptuous offerings. Grant lastly, that Telemachus and I may successfully accomplish the task that brings us here in our swift black ship and afterwards reach home safely.' ${ }^{16}$

As can be deduced from the aforementioned passage, such offerings were made prior to departure in supplication for a safe journey or at the end in thanksgiving for arriving safely. There are also references to rituals and prayers at sea performed or recited at sea - mainly to counter perilous situations. Jewish seafarers for example resorted to the purchase of new ceramic containers onto which 'holy names' and invocations were inscribed before being thrown into the sea. Through this action it was believed that the divine powers would be appeased and hence the

\footnotetext{
${ }^{16}$ The Odyssey 3:60.
} 
sea calmed. ${ }^{17}$ Through anthropological studies it is also known that fisherfolk recited special prayers which were normally variations of prayers said on land. Other prayers were purposely developed for specific situations at sea. Fisherfolk from Syracuse in Sicily prayed to St. Anne during storms but to keep themselves safe from lightning bolts they recited a specific prayer to St. Barbara. There also existed special prayers that the wives of fishermen recited whilst the men were out at sea in difficult conditions. ${ }^{18}$

Mediterranean seafarers uttered prayers at any sign of approaching danger. An early nineteenth century English traveller, J. Webster, gives this detailed account of prayers said off Sicily on board the vessel he was sailing:

'It became very cloudy, and the ship, unable to make way, turned back toward Sicily. Shortly after, as we were going on rapidly though roughly, the owner of the vessel came on deck, carrying a little bell and a string of beads. After a brief consultation with the captain, he summoned the whole crew, who ranged themselves half on either side of the deck. The bell rang to give notice of the time for the commencing of the Aves, and one side chanted the first, and then the other took up the remaining in a higher key. The bell sounded, and Gloria Patri was sung, after ten Aves had been chanted in the manner just described. After this, each crossing himself, and falling on his knees, begun muttering in a hurried whisper the Litany of the Virgin, commencing with Kyrie Eleison, and giving about fifty epithets to the Madonna. Another chant completed the round, which, however, was no sooner done, than they recommenced the Aves - singing ten of them as before, repeating the Gloria, the Kyrie Eleison, and the concluding song, which process was gone through a third, fourth and fifth time. Then the crew dispersed, but their devotions were not over, for a few seconds after: one of the seamen struck up a long religious hymn, in the chorus of which, all his messmates most devoutly joined.' ${ }^{19}$

There is a clear division between formal prayer (Aves, Gloria and Kyrei Eleison) which the author recognises and the less formal 'religious hymn' recited by the sailors in a less structured and informal manner.

Another scenario that provided the context for rituals at sea was that of naval combat. Sacrifices and offerings were made to deities prior to meeting in battle. Thus, during the Persian Wars, before the Battle of Salamis was about to commence, Themistocles sacrificed three Persians alongside the admiral's trireme as an offering to Dionysius

\footnotetext{
17 Shelamo Dov Goitein, A Mediterranean Society: The Jewish Communities of the Arab World as Portrayed in the Documents of the Cairo Geniza, volume I: Economic Foundations (Berkeley and Los Angeles: University of California Press, 1967), I: 324.

18 Augusto Aliffi, Mariarosa Malesani and Liliana Gissara, Pesca e pescatori nel siracusano (Syracuse: Syrakosia, 2007), p. 82.

19 James Webster, Travels through the Crimea, Turkey and Egypt; Performed during the Years 1825-28 (London: Colburn and Bentley, 1830), pp. 246-247.
}

Carnivorous. ${ }^{20}$ After this same battle the victorious Greeks offered thanksgiving to Zeus and 'danced to celebrate their triumph with shouts and stamping of feet'. ${ }^{21}$ After a battle the victors would gather captured weapons, oars and even bronze rams and use these to set up a trophy, generally dedicated to the gods. Augustus gathered captured rams from enemy vessels he defeated at Actium and constructed an expansive memorial that was dedicated to Neptune and Mars. ${ }^{22}$ In more recent times, an account reaches us through an Englishman serving as a slave on a Moorish corsair vessel. He describes how, before launching an attack, the Muslim corsairs performed a ritual at the bow of the ship. This consisted of the sacrificing of a goat and jettisoning parts of the animal overboard whilst reciting incantations. This highly ritualised phase of the attack was aimed at protecting those on board as well as facilitating the capture of the opposing ship. ${ }^{23}$

The 'birth and death' of a seagoing vessel were also marked by ritual. A seventeenth-century diary kept by a chaplain, Henry Teonge (d. 1690), serving on board an English vessel contains a detailed description of a vessel being launched in Malta:

'This day we saw a great of solemnity at the launching of a new brigantine of twenty three oars, built on the shore very near the water. They hoisted in her three flags yesterday, and this day by 12 they had turned her head near the water; when as a great multitude of people gathered together, with several of their knights and men of quality, and a cloud of friars and churchmen. They were at least two hours in their benedictions, in the nature of hymns and other their ceremonies; their trumpets and other music playing often. At last two friars and an attendant went in to her, and kneeling down prayed half an hour, and laid their hands on every mast and other places of the vessel, and sprinkled her all over with holy water. ${ }^{24}$

On the other hand, an excellent example of a ritual marking the end of a vessel's life can be observed on the island of Vis in Croatia. For the feast of St. Nicholas (5th of December), islanders drag an old boat up a hill in the town of Komiza to a church that is dedicated to the same saint. It is offered as a token for the salvation of other boats as well as for the rebirth of the boat that has just ceased to exist. ${ }^{25}$

\footnotetext{
20 Plutarch's Lives, volumes I-XI, translated by Bernadotte Perrin (Cambridge, MA: Loeb Classical Library, 1914), II: 13.

${ }^{21}$ John Hale, Lords of the Sea: The Epic Story of the Athenian Navy and the Birth of Democracy (New York: Viking, 2009), p. 71.

${ }^{22}$ William M. Murray and Photios M. Petsas, 'Octavian's campsite memorial for the Actian War', Transactions of the American Philosophical Society, 79.4 (1989).

${ }^{23}$ Giles Milton, White Gold: The Extraordinary Story of Thomas Pellow and North Africa's One Million European Slaves (London: Sceptre, 2005), p. 247.

${ }^{24}$ G.E. Manwaring (ed.), The Diary of Henry Teonge Chaplain on Board H.M.'s Ships Assistance, Bristol, and Royal Oak 1675-79 (London: George Routledge \& Sons, 1928), p. 128.

${ }^{25}$ Joško Buljubašić and Eni Božanić, 'The ritual of boat incineration on the Island of Vis, Croatia: an interpretation', International Journal of Intangible Heritage, 7 (2012): 17.
} 

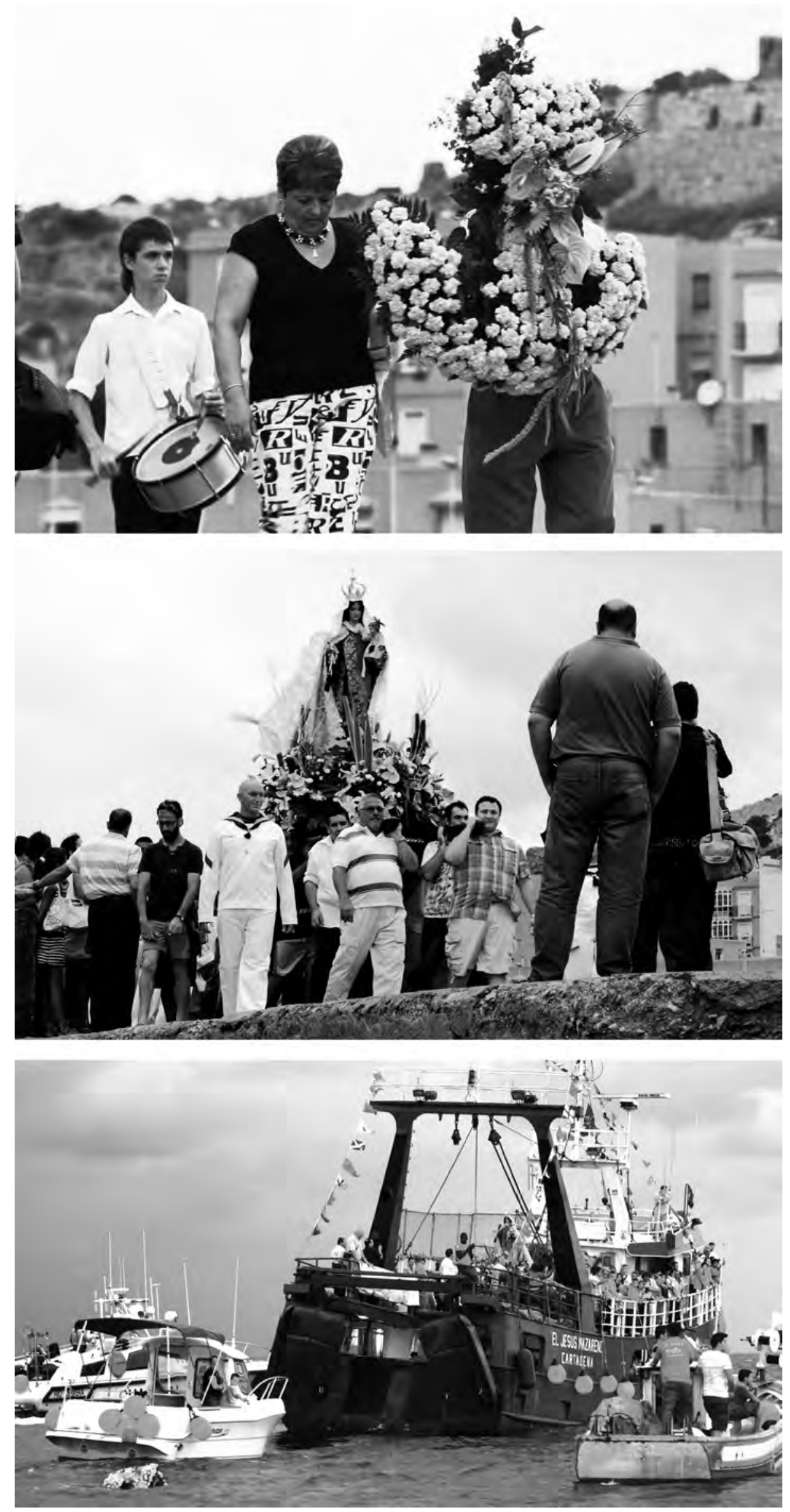

Fig. 3: VARIOUS STAGES OF THE MARITIME PROCESSION HELD ANNUALLY IN CARTAGENA, SPAIN (PHOTOS T. GAMBIN). 
A ritual that is still performed in many ports throughout the Mediterranean is that of processions at sea. One such procession takes place in Cartagena, Spain, on the 16th of July. The feast celebrating the Virgen de Carmen starts with a 'maritime procession' that is followed by numerous people including fishermen, sailors and their family members. At some point during the procession a minute of silence is observed so as to pay respect to the deceased members of the maritime community. Once the statue reaches the fishing port it is loaded onto a large trawler together with priests (in full regalia) and numerous other officials. This boat makes its way out to Cartagena Bay followed by a large number of fishing boats and pleasure craft. Of importance is the fact that for this occasion, fishermen are joined by their wives and children in a domain that is usually reserved for men. Once the boats reach a certain point, prayers are said and a wreath shaped as an anchor is thrown into the sea. By taking the statue of the Virgen de Carmen out to sea the fisherman are ensuring that she knows where they work and will thus be in a better position to keep a watchful eye over them when at sea (Fig. 3).

Prayer recited by participants of the Cartagena procession:

\author{
'Salve Marinera \\ Hail ...! Star of the Sea, \\ In the seas - Iris of eternal bliss. \\ Hail ...! Phoenix beauty, \\ Mother of Divine Love \\ In your people \\ A sorrow \\ Your mercy of comfort; \\ Fervent \\ Reach the Sky \\ And to you \\ And to you, our cry \\ Hail! Hail! Star of the Sea ... \\ Hail ...! Star of the Sea \\ Hail! Hail! Hail! Hail!'26
}

Such processions take place in many coastal towns of the Mediterranean although they may differ slightly in form. At Porticello in Sicily for example, it is a painting of Maria Santissima del Lume that is carried out to sea on a fishing boat towards Capo Zafferano where a chapel dedicated to the same saint is situated close to a lighthouse. Fishermen enter their boat into a form of lottery so as to be selected to transport the painting. Other boats carry the band, dignitaries and family members. Once landed on the headland, fireworks mark the journey of the painting towards the chapel. Boats and their occupants line up in the anchorage below with people making their way up to the chapel to leave their offering at the altar. The ritual comes to an end when all have deposited their offerings and return to their boats to return home. Not all processions are dedicated to Our Lady: in Mazara del Vallo, Sicily, it is the

\footnotetext{
${ }^{26}$ All observations including the recording of prayers were done by the present author during fieldwork in Cartagena in July 2008.
}

statue if San Vito that is taken out to sea. ${ }^{27}$ In Birżebbuga, Malta, I have observed that the statue of St. Peter is taken out twice - once each by the followers of rival band clubs. For these separate occasions, the boats and statue are clad in the respective colours (red and green) of the band clubs.

What these rituals have in common is that the deities are removed from the relative safety of their normal resting place, the church, and are transported to what is an unfamiliar realm. It seems as though those involved are asking their deity to see for her/himself the conditions that they face every day. In exchange for prayers and offerings, the believers ask for compassion. Of utmost importance is the context within which these specific rituals take place, discussed below.

\section{Maritime cultic landscapes}

In ancient times, natural features such as offshore islands, promontories and headlands were, for a number of positive and negative reasons, considered by seafarers as significant places. ${ }^{28}$ Various factors influenced their perception. Firstly, the prevailing conditions around such features often differ from what one encounters in the open sea. Such distinct weather conditions are caused by a combination of factors including wind patterns, changes in seabed topography and wave/swell combinations. When taken all together these create confused seas and unfavourable conditions. One may think that this would have led seafarers to avoid such areas which brings us to the second factor that influenced the perception of ancient mariners - that of recognition. Offshore islands and headlands provided navigators with indispensable landmarks for navigation. Through the recognition of these features ancient seafarers could not only work out their whereabouts but also set a new course. Furthermore, islands offered vessels the possibility for rest, replenishment and shelter. At one and the same time therefore islands and headlands were both dangerous and desirable. Whether they liked it or not, ancient mariners had to come to terms with this duality. In this light, it is not surprising that such features within the natural landscape assumed roles that transcended the pragmatic aspects of a journey. These features evolved into focal points where people at sea could connect with their maritime deities.

Such a concept was discussed in detail in the thought provoking publication The Corrupting Sea, in which Peregrine Horden and Nicholas Purcell propound the idea of 'Religion of Mobility' whereby: ‘... navigation, which is so essential a component of Mediterranean life, is also paralleled in a cultic topography. Particular features of the sea-voyage are marked as sacred, especially those coastal havens, springs or landmarks that are most important to the business of navigation'. ${ }^{29}$ Seafarers sailing in the

\footnotetext{
${ }^{27}$ Orietta Sorgi, 'La pesca e i suoi numi tutelari. Il culto di Maria Santissima del Lume a Porticello', in Santi a mare: ritualita' e devozione nelle communita' costiere siciliane, eds. Ignazio Buttita and Maria Emanuela Palmisano (Palermo: Regione Siciliana, 2009), p. 62.

${ }^{28}$ Jamie Morton, The Role of the Physical Environment in Ancient Greek Seafaring (Leiden: E.J. Brill, 2001), pp. 185-193.

${ }^{29}$ Peregrine Horden and Nicholas Purcell, The Corrupting Sea: A Study
} 


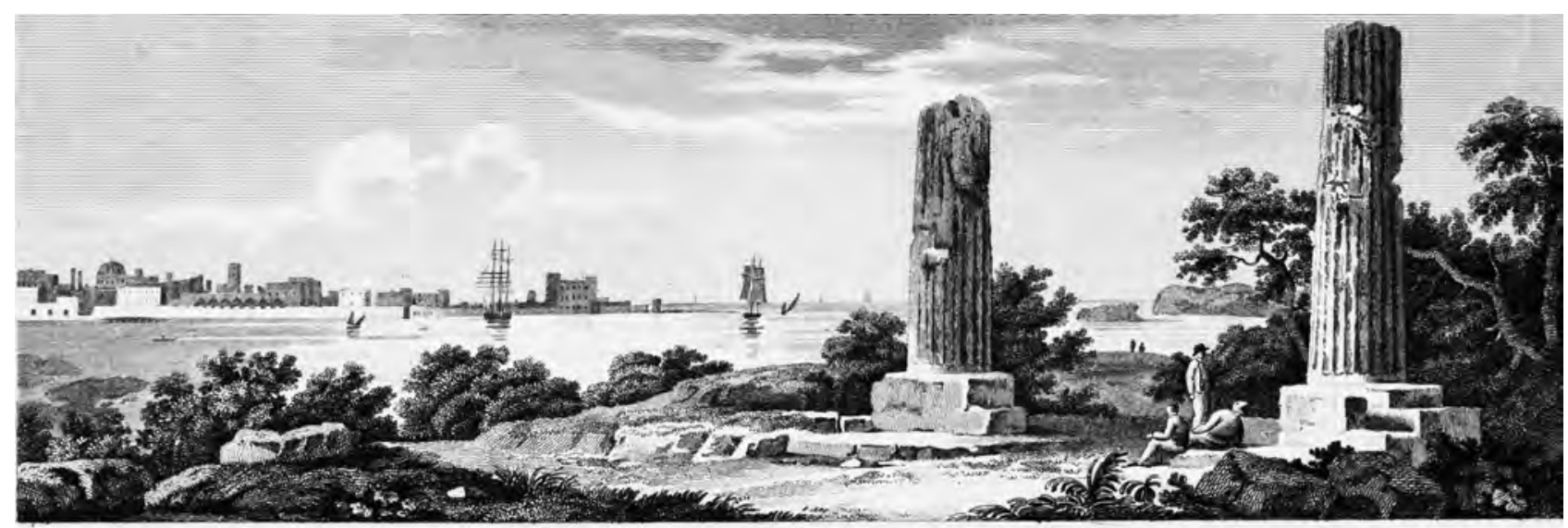

View of Syracuse, from the Ruins of the Temple of Jupiter Olympus.

FIG. 4: EARLY NINETEENTH-CENTURY SKETCH SHOWING THE ARCHAEOLOGICAL REMAINS THAT PROVIDE GOOD INDICATORS FOR
VESSELS ENTERING THE HARBOUR (AFTER WILLIAM SMYTH 1823; COURTESY OF THE WIGNACOURT MUSEUM, RABAT-MALTA).

Mediterranean would thus find themselves moving within a maritime cultic landscape. This meant making visible features such as temples or shrines that would be instantly recognisable by those sailing in their vicinity. Most ancient cultures with a seafaring element constructed or adopted such 'seaward looking' places of worship in places of navigational importance. Pushed by a desire to understand better what pushed the ancient Greeks to construct the massive temple of Poseidon at Sunion, Ellen Churchill Semple studied and compiled a list of similar sites and coined the term 'templed promontories'. ${ }^{30}$ By doing so she was able to highlight this phenomenon as being panMediterranean. It was of course not just the Greeks that built such sites. The Phoenicians too constructed or, as in the case of Tas-Silg in Malta, adopted existing structures for their own purposes. ${ }^{31}$ With the spread of Roman hegemony in the Mediterranean many of these coastal temples were absorbed into the Roman maritime milieu. Deities to which such temples were dedicated included, amongst others, Astarte, Poseidon, Hermes and Hercules. ${ }^{32}$ The usefulness of ancient structures as navigational markers was noted many centuries later by the renowned British hydrographer William Smyth (d. 1865). In his The Hydrography of Sicily and Malta he includes numerous archaeological remains. Within the port of Syracuse in Sicily he notes on the map 'these two remaining columns [from an ancient temple] are an excellent leading mark in' (Fig. 4). ${ }^{33}$

\footnotetext{
of Mediterranean History (Oxford: Blackwell Publishers, 2000), p. 440. ${ }^{30}$ Ellen Churchill Semple, 'The templed promontories of the Ancient Mediterranean’, Geographical Review, 17.3 (1927): 357.

${ }^{31}$ Antonia Ciasca, 'Le Isole Maltesi e il Mediterraneo Fenicio', Malta Archaeological Review, 3 (1999): 21-25.

${ }^{32}$ See Nicholas C. Vella, 'A maritime perspective: looking for Hermes in an ancient seascape', in The Greek Islands and the Sea, Proceedings of an International Colloquium held at the Hellenistic Institute, Royal Holloway, University of London, 21-22 September 2001, eds. Julian Chrysostomides, Charalambos Dendrinos and Jonathan Harris (Surrey: Camberley, 2004): 33-57.

${ }^{33}$ William H. Smyth, The Hydrography of Sicily, Malta and the Adjacent Islands (London: Office of the Admiralty, 1823), Plate 21.
}

Maritime cultic landscapes did not cease to exist with the end of pagan antiquity. In many parts of the Mediterranean, Christian saints assumed the role previously held by the aforementioned deities. As previously discussed, Our Lady becomes the prime protectress of Christian seafarers. Expressions of such devotion are, for example, reflected in the cults of Madonna of Stella Maris (Star of the Sea) and Madonna di Porto Salvo (Safe Port). Other indicators of the link between saints and the sea may be deduced from place names - numerous headlands, bays and anchorages throughout the Mediterranean are named after Our Lady and other deities. Porto San Nicolo and Porto San Paolo in Sardinia, Sainte Marie de la Mer in France, San Niklaw in Malta and Punta de San Cristobal in Spain are but some examples.

The importance of chapels and churches for medieval seafarers is highlighted in contemporary sailing instructions known as portolani. In an echo from ancient times, chapels were used as distinct markers for recognising one's whereabouts as well as for the positioning of one's vessel in the an ideal position within an anchorage. Medieval sailing instructions for the Maltese Islands list chapels dedicated to St. George, St. Paul and St. Lawrence alongside others dedicated to Our Lady. ${ }^{34}$ Some of these sites retained this function well into the seventeenth century with the Chapel of St. Paul in Saint Paul's Bay used as a marker for the ideal anchoring zone. ${ }^{35}$ Other religious features such as crosses and statues were often placed in coastal areas and local fishermen used these as markers. An early modern pilot book drawn by a Christian mariner clearly indicates minarets as navigational markers on the otherwise featureless coast of North Africa. These religious buildings probably held similar religious significance for Islamic

\footnotetext{
34 Arnold Cassola, 'The Maltese toponomy in three Ancient Italian portulans (1296-1490)’, Al-Masāq Studia Arabo-Islamica Mediterranea, International Journal of Arabo-Islamic Mediterranean Studies, 5 (1992): 47-64.

${ }^{35}$ Timmy Gambin, 'Maritime links of chapels dedicated to St Paul', in St Paul in Malta and the Shaping of a Nation's Identity, eds. Joseph Azzopardi and Anthony Pace (Malta: OPM, 2010; first edition), pp. 147157.
} 
seafarers as did chapels and churches for their Christian counterparts.

Islamic respect for certain aspects of the Mediterranean's early modern maritime cultic landscape can be garnered from two contemporary examples. The first comes from the Strait of Gibraltar, where Muslim ships saluted a hermit: 'Apes Hill is a rock, of great height and extremely steep: on the top of it lives a Marabout wizard or enchanter; and what vessel so ever of the Turks [Muslim] goes by gives him a gun as she goes, to beg a fortunate voyage' ${ }^{36}$ The second example comes to us from the island of Lampedusa in the central Mediterranean. Items of food and drink were left at a shrine by both Muslim and Christian seafarers. These supplies were freely available to all mariners in need but it was believed that should mariners take on more supplies than required supernatural powers would prevent their vessel from leaving the port. ${ }^{37}$ This show of solidarity amongst seafarers is made all the more astounding when one considers that during this period many Muslim and Christian seafarers were waging holy war against each other.

It was not only places of worship that assumed navigational roles but also burial places. Elpenor, a comrade of Odysseus, is buried with full armour (and therefore honour) in a barrow with an oar to mark his resting place. The oar also reminded the living that it was a seafarer, more specifically a rower, who was buried there. ${ }^{38}$ In the past, such 'temporary' burials must have been commonplace amongst seafarers. Men succumbing to combat wounds or even natural causes whilst serving at sea would have had to be buried away from their homeland. The 'temporary' nature of this type of burial marker (an oar for example would gradually perish or be stolen) would explain their rarity in the archaeological record. ${ }^{39}$ The description of another grave from the Odyssey leaves one in no doubt as to the intentions of those that built it:

'... over their bones we soldiers of the mighty Argive force built up a great and glorious mound, on a foreland jutting out over the broad waters of the Hellespont, so that it might be seen far out at sea by the men of today and future ages. ${ }^{30}$

Due to the heroic nature of the persons inhumed this monumental burial was clearly grander and of a more permanent nature than Elpenor's.

There is another very interesting example of a 'temporary' maritime cultic landscape. This particular form is of major interest due to the fact that is situated out at sea. When preparing the complex nets needed to trap tuna off the island of Favignana in Sicily, special attention was given to

\footnotetext{
${ }^{36}$ Manwaring, 47.

${ }^{37}$ Catherine A. Philips (trans.), The Life of Captain Alonso de Contreras, written by himself (New York: New York, A. A. Knopf, 1926), p. 45.

${ }^{38}$ The Odyssey 11:60-80.

${ }^{39}$ Should death occur whilst the vessel was underway then the individuals would be buried at sea.

${ }^{40}$ The Odyssey 24:80.
}

both the practical and the divine. The fish had to be guided through a series of chambers into the final one known as the 'chamber of death' where the tuna would eventually be killed and harvested. The entire set up was overseen by a cross that was adorned by numerous holy pictures: representations of Our Lady (mainly) and St. Joseph with palm leaves for decoration. ${ }^{41}$ In Mellieha Bay in Malta, the cross present on a similar complex of nets was positioned so as to face the village sanctuary dedicated to Our Lady that stands on a hill that dominates the bay where this activity took place. Such practices were observed up to the demise of this fishing technique a few years ago.

\section{Dry offerings}

This category covers examples of various types of offerings made to Mediterranean deities over time. These are not sacrifices that by their very nature are perishable and/or consumable but rather gifts of a more permanent nature. In the Bronze Age, anchors seemed to have formed one of the most popular forms of dry offerings. Votive anchors, for example, were noted in 'sacred contexts in the great port-towns of Byblos, Ugarit and Kition as well as at minor Levantine sites' ${ }^{42}$ Such offerings bring together the previously discussed notions of deities, ritual and maritime cultic landscapes. It is not possible to ascertain all three factors for each and every site where such offerings have been found, however. Although traces of such practices can be lifted from throughout the Mediterranean's history, we are not always presented with details related to the rituals involved with the actual placing of such objects.

One prime example is the placing of ex-voto paintings in churches. ${ }^{43}$ Walls of numerous churches throughout the Mediterranean are adorned with representations of maritime scenes - often men, or groups of men, in difficulty due to storms or attacks on their vessels. In these particular circumstances vows are made that tie the individual (or group) to submit an offering to a particular deity that is housed in a particular church or chapel (Fig. 5). Such churches and chapels are not necessarily situated on the coast and choice may be determined by parish loyalty, tradition and/or belief in the power of a particular saint. Others, such as Notre Dame de la Garde, are very much part of the maritime cultic landscape. This particular church is situated atop a hill and is visible from far out at sea. With a large statue of Our Lady painted in gold on its roof, it is in itself an important navigational marker for those sailing off Marseille harbour. Although seafarers seemed to have preferred placing ex-voto paintings in shrines dedicated to Our Lady (as in Marseille), there are other saints whose shrines were adorned with such

\footnotetext{
${ }^{41}$ Ignazio Buttita, 'Cultura marinara, ricerca folklorica e turismo 'culturale' ', in Sicilia: stato dell'arte e prospettive, in Santi e mare, eds. Ignazio E. Buttita and Maria Emanuela Palmisano (Palermo, Regione Siciliana, 2009), pp. 25-44, in particular pp. 26-27.

${ }^{42}$ Honor Frost, 'Two Cypriot anchors', in Italy and Cyprus in Antiquity 1500-450 BC, eds. Larissa Bonfante and Vassos Karageorghis (Nicosia: Costakis and Leto Severis Foundation, 2001), pp. 61-76.

${ }^{43}$ See Isabelle Borg, The Maritime Ex-Voto: a culture of thanksgiving in Malta (Malta: Heritage Books, 2005)
} 


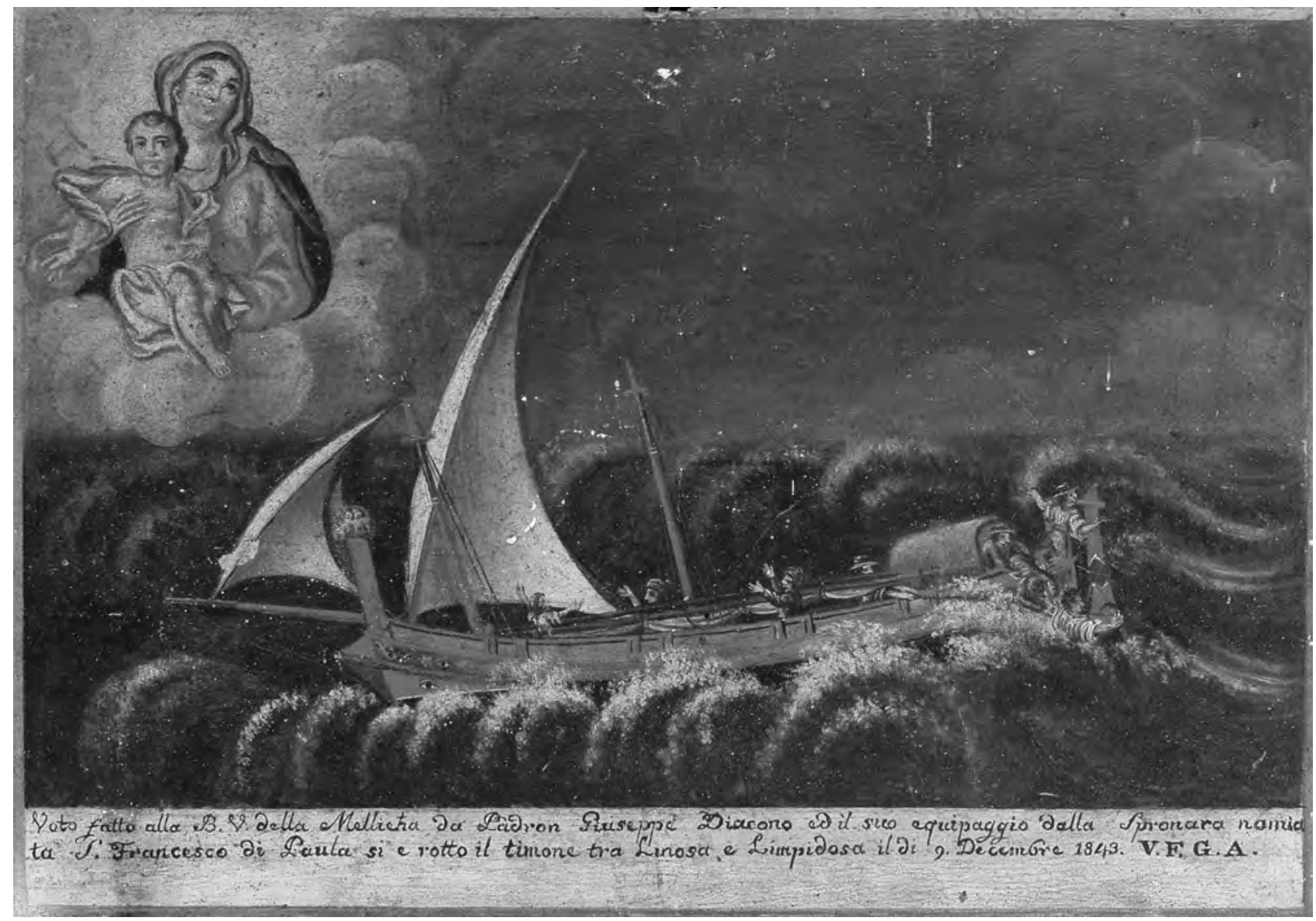

Fig. 5: A typical MediterRanean EX-VOto PAINTING FROM A CHURCH IN MALTA (PHOTO COURTESY OF MIDSEA BOOKS LIMITED).

offerings. The church of San Lorenzo in Liguria is one such example although the paintings within this shrine still contain representations of Our Lady. ${ }^{44}$ In Vilanova i la Geltru in Catalonia are a number of paintings with dual dedications - those of Our Lady and St. Christopher, patron saint of travellers, mariners and ferrymen. ${ }^{45}$ We do sometimes have information on the individual or group commissioning the painting but the artists more often than not remain anonymous.

Another form of dry offering that may be considered to be in a similar vein as ex-voto paintings are ship models. In the Tarragona area of Catalonia for example, ship models can be found hanging from the ceilings of numerous churches. Unlike their painted counterparts, such models and dioramas do not have religious representations. ${ }^{46}$ Despite this, their presence in churches and chapels in Mediterranean, as well as in other parts of Europe, leaves one in no doubt as to their votive nature. Poorer

\footnotetext{
${ }^{44}$ P. Spagiari, 'Miracolose apparizioni e prodigiosi avvenimenti', in $\mathrm{La}$ Devozione e il Mare: aspetti di fede e religiosita' in Liguria, eds. Rinaldo Luccardini and Maria Teresa Orengo (Genoa, Tormena Editore, 2000), pp. 25-54.

${ }^{45}$ Anoni Sella and Enric Garcia, Creencias del Mar (Barcelona: Museu Maritim, 2003), pp. 178-179.

${ }^{46}$ Selia and Garcia, 187-191.
}

persons, not being able to afford the commissioning of paintings or models may have offered simpler forms of ship representations. Ship graffiti are found on both the exterior and interior walls of numerous churches and chapels of the Maltese Islands. It is believed that these ship representations had similar functions to ex-voto paintings but differed in form; different, because very rarely did these ever include any sacred iconography. ${ }^{47} \mathrm{It}$ is reasonable to assume that the individuals who inscribed these ships travelled to the shrines specifically for this purpose. If they had simply wanted to express their 'art' it would have been easy enough to inscribe the walls of public buildings. ${ }^{48}$ Other offerings that are maritime in nature that are sometimes found in chapels and churches include lengths of rope, planks and other miscellaneous pieces that may have played a vital role in saving a life at sea. The church of Our Lady in Qala on the island of Gozo was, up until recently, adorned with such offerings. ${ }^{49}$ Other religious edifices received offerings. Corsairs operating

\footnotetext{
${ }^{47}$ See Joseph Muscat, Il-Graffiti Marittimi Maltin (Valetta: PIN Books, 2002).

${ }^{48}$ There do exist ship graffiti on public and private buildings in Malta but not comparable to the quantity inscribed on churches.

${ }^{49}$ Frank Theuma, 'A view of the sea: the maritime graffiti of the Immaculate Conception Chapel, Qala, Gozo’, Melita Historica, 13 (2003-4): 413.
} 
and setting out of Malta in the seventeenth and eighteenth centuries offered part of their proceeds as the Cinque Lancie - the five lances. These consisted of five shares taken from captured booty. Amongst the beneficiaries of these shares were the nuns of the Convent of St. Ursula in Valletta. This payment was made so that the nuns would 'pray continuously for victory against the Infidel'. ${ }^{50}$

There are some dry offerings that can be directly linked to ritual. When, through the capture at sea of a Greek grain ship, Messina was delivered from famine in the seventeenth century, the senate of the city ordered the construction of a vascelluzzo (ship model) in silver. ${ }^{51}$ To this day, the model is housed in the main church of the city. The ritual linked to the model entails that it is adorned with lengths of grain and carried around the streets once a year in commemoration of the favour received by the city. ${ }^{52}$ This can be considered as a reverse of the aforementioned processions at sea. In this particular case it is the ship that travels through an unfamiliar landscape, that of the urban centre of Messina. Elsewhere in Sicily there existed less formal offerings and rituals than those just described. The streets of the fishermen's quarters were locations for more 'casual' religious activity linked to the sea. Homemade braids were hung on the shrine of Our Lady in Mirabella in thanksgiving for some form of grace received (generally linked to prayers for those working out at sea). ${ }^{53}$

\section{Concluding remarks}

Through the analytical categories described above and the examples these include, I hope that I have sufficiently demonstrated the link between people who use and travel on the sea and the divine as well as the plethora of ways that such a link was manifested across time and space. In no way can this paper be considered a conclusive and/or comprehensive study, however. The subject needs, and indeed deserves further in-depth studies. On the other hand, this paper is intended to act as a stimulus for those with an interest in the subject. It will hopefully stimulate other researchers to delve into and explore aspects of their local facets of maritime religion that they may know and that may be placed within the broader context alluded to on these pages. This is true not just for the Mediterranean but for any place where the sea has touched human lives.

\footnotetext{
${ }^{50}$ Peter Earle, Corsairs of Malta and Barbary (London: Sidgwick and Jackson, 1970), p. 126.

51 See Carmelina Gugliuzzo, 'The Holy Vessel: the Vascelluzzo of Messina during the early modern period' in this volume.

${ }^{52}$ Elina Gugliuzzo, Fervori municipali: Feste a Malta e Messina in eta' moderna (Messina: Armando Siciliano Editore, 2006), p. 79.
}

$\overline{{ }^{53} \text { Aliffi and Malesani, p. } 83}$ 